\title{
Covid-19: MPs call on Public Health England to publish evidence for decision to drop community testing
}

\author{
Jacqui Wise
}

London

A cross party group of MPs has said that Public Health England's failure to publish the evidence behind its decision to discontinue community testing at the start of the covid-19 outbreak is "unacceptable."

In a 19 page letter to the prime minister, the Science and Technology Committee called for publication of the evidence base and rationale informing Public Health England's decision to concentrate testing for covid-19 in a limited number of its own laboratories and to expand testing capacity gradually, rather than surging capacity through a large number of available laboratories in research institutes, universities, and the public and private sectors. ${ }^{1}$

This had led to the government announcing on 12 March that testing would stop in the community and would occur principally within hospitals - a decision that was "one of the most consequential made during [the] crisis," MPs said in the letter. "Amongst other consequences, it meant that residents in care homes-even those displaying covid-19 symptoms—and care home workers could not be tested at a time when the spread of the virus was at its most rampant."

Their letter continued, "The failure of PHE [Public Health England] to publish the evidence on which its testing policy was based is unacceptable for a decision that may have had such significant consequences. The absence of disclosure of the evidence behind this decision may indicate no rigorous assessment was in fact made by PHE of other countries' approach to testing."

It said that testing capacity had been inadequate for most of the pandemic so far, arguing that "capacity was not increased early enough or boldly enough. Capacity drove strategy rather than strategy driving capacity." It added that it was not clear that lessons had been learnt from the delays to testing.

\section{Transparency}

The letter detailed 10 key lessons the UK government should learn from its experience of handling the first months of the epidemic, on the basis of evidence given by scientists and other experts during six public evidence sessions.

The MPs wrote, "The transparency around scientific advice has not always been as clear as it should have been." They urged the government to regularly update the public list of members of the Scientific Advisory Group for Emergencies (SAGE) and to publish the papers on which the group draws its advice, as well as the scientific advice that has informed government decisions.

The letter called on the government to "urgently" build up capacity for contact tracing to manage the easing of lockdown measures and minimise the risk of a second peak of infections. It said that the government should set out a clear approach for managing the risks around asymptomatic transmission of covid-19.

Another recommendation was the systematic recording of the ethnicity of people who die from covid-19, to help understand the disproportionate numbers of deaths in patients from ethnic minority backgrounds.

The committee chair, Greg Clark, said, "Greater transparency around scientific advice; putting capacity in place in advance of need, such as in testing and vaccines; collecting more data earlier; and learning from other countries' approaches are some of the early lessons of this pandemic that are relevant to further decisions that will need to be taken during the weeks and months ahead."

UK Parliament. Committee writes to the prime minister: lessons learned so far from the covid-19 pandemic. 19 May 2020. https://committees.parliament.uk/committee/135/scienceand-technology-committee-commons/news/146472/committee-writes-to-the-prime-ministerlessons-learned-so-far-from-the-covid19-pandemic/.

Published by the BMJ Publishing Group Limited. For permission to use (where not already granted under a licence) please go to http://group.bmi.com/group/rights-licensing/ permissions 